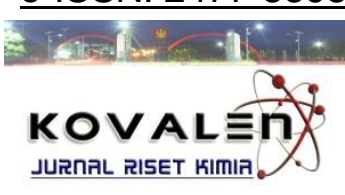

\title{
UJI AKTIVITAS ANTIBAKTERI EKSTRAK BUNGA TEMBELEKAN (Lantana camara Linn) DARI BEBERAPA TINGKAT KEPOLARAN PELARUT
}

\section{[Antibacterial Activity Assay of Elastic Extract (Lantana camara Linn) in Various Level Of Solvent Polarity]}

\author{
Parwati $^{{ }^{*}}$, Ahmad Ridhay ${ }^{1}$, Syamsuddin ${ }^{1}$ \\ 1) Jurusan Kimia, Fakultas MIPA, Universitas Tadulako, Palu \\ J. Soekarno Hatta Km.9, Kampus Bumi Tadulako Tondo Palu, Telp. 0451- 422611
}

*)Coresponding author: parwaticois95@gmail.com (082233651692)

Diterima 5 Desember 2018, Disetujui 11 Februari 2019

\begin{abstract}
A study was conducted on the antibacterial activity test of elastic extract (Lantana camara Linn.) with several levels of solvent polarity. The purpose of this research is to discover the antibacterial activity of elastic extract (Lantana camara Linn.) against Gram positive bacteria (Streptococcus mutans) and gram negative bacteria (Vibrio cholerae) based on polarity level of solvent. The method of extraction used in this research was maceration method with 3 levels of solvent polarity, starting from non polar solvent ( $n$-hexane), followed by semipolar solvent (ethyl acetate) and polar solvent (ethanol). The antibacterial activity test was performed by diffusion well test, and the observed parameter was the inhibitory diameter. The results showed that ethyl acetate extract gave the highest inhibition of 17,33 $\mathrm{mm}$ in gram negative bacteria (Vibrio cholera) and ethanol extract of $13,3 \mathrm{~mm}$ in Gram positive bacteria (Streptococcus mutans).
\end{abstract}

Keywords: Tembelekan (Lantana camara), Flower Potential Extract, Resistor, Antibacterial.

\begin{abstract}
ABSTRAK
Telah dilakukan penelitian tentang Uji aktivitas antibakteri ekstrak bunga tembelekan (Lantana camara Linn.) dari beberapa tingkat kepolaran pelarut. Tujuan penelitian ini adalah mengetahui berapa daya hambat ekstrak bunga tembelekan terhadap bakteri gram positif (Streptococcus mutans) dan bakteri gram negatif (Vibrio cholerae) berdasarkan tingkat kepolaran pelarut. Metode ekstraksi yang digunakan dalam penelitian ini yaitu metode maserasi dengan 3 tingkat polaritas pelarut yang dimulai dari pelarut non polar ( $n$-heksan), diikuti dengan pelarut semipolar (etil asetat) dan pelarut polar (etanol). Pengujian aktivitas antibakteri dilakukan dengan uji metode sumur difusi, dan parameter yang diamati adalah diameter daya hambat. Hasil penelitian menunjukan bahwa ekstrak etil asetat memberikan daya hambat tertinggi $17.33 \mathrm{~mm}$ pada bakteri gram negatif (Vibrio cholera) dan ektrak etanol 13,2 $\mathrm{mm}$ pada bakteri gram positif (Streptococcus mutans).
\end{abstract}

Kata kunci: Ekstak bunga tembelekan, Daya hambat, Antibakteri. 


\section{LATAR BELAKANG}

Tembelekan (Lantara camara) merupakan jenis tanaman asli daerah tropis seperti Amerika Tengah dan Selatan yang tergolong dalam family verbenaceae. Tanaman tembelakan adalah tamanan liar yang dapat tumbuh subur pada daerah dengan ketinggian $1.700 \mathrm{~m}$ dpl. Tanaman ini termasuk dalam tanaman perdu yang sangat mudah diperoleh karena tanaman tembelekan ini hidup di dataran tropis. Lantana camara pada awalnya merupakan tumbuhan liar yang tidak diketahui manfaatnya, sekarang merupakan tumbuhan budidaya yang populer dan hampir seluruh bagian tanaman ini dapat digunakan untuk kebutuhan pengobatan penyakit seperti luka, bisul peluruh air seni, peluruh keringat, peluruh haid, penurun panas, obat bengkak, encok dan batuk (Mardisiswojoyo dan Mangansudarso, 1968).

Manfaat yang banyak dari tembelekan dipengaruhi oleh kandungan kimia yang terkandung didalamnnya atau dikenal dengan metabolit sekunder. Senyawa metabolit sekunder dapat berupa flavonoid, alkaloid, tanin, sapponin, steroid dan triterpenoid (Harbone, 1987). Metabolit sekunder ada yang berperan sebagai antimikroba, antibiotik, antioksidan, antikanker, anti koagulan darah dan dapat menghambat efek karsinogenik (Copriady et al., 2005 dalam Handayani). Uji metabolit sekunder sebagai antibakteri selalu didahului dengan ekstraksi pelarut yang bertujuan untuk menarik metabolit sekunder yang bersifat antibakteri.

Antimikroba merupakan zat kimia yang memiliki khasiat untuk menghambat atau membunuh pertumbuhan mikroorganisme, antimikroba dapat dibagi menjadi antibakteri, antifungi, antivirus dan antiprotozoal berdasarkan mikroorganisme yang dimatikan atau dihambat pertumbuhannya (Tjay dan Kirana, 2002). Senyawa antimikroba dari tumbuhan dapat diperoleh dengan cara ekstraksi dengan menggunakan pelarut organik. Jumlah dan jenis senyawa antinikroba akan salinge berbeda sesuai dengan polaritas pelarut (Fajrullah, 2014). Penelitian yang telah dilakukan oleh Rijay (2014), menyatakan bahwa ekstrak pekat etanol daun tembelekan sangat potensial sebagai obat luka, dengan konsentrasi uji 30\% dan lama penyembuhan luka 3 hari. Menurut penelitian (Iwan et al.., 2011) Ekstrak nheksan bunga tumbuhan $L$. camara memiliki zona hambat yang lebih tinggi terhadap bakteri gram positif dan gram negatif yaitu $S$. aeureus dan bakteri $E$. coli karena memiliki ekstrak yang aktif. Secara fitokimia, tembelakan mengandung senyawa golongan alkaloid, flavonoid, dan steroid (Asma et al., 2015). Maka perlu dilakukan penelitian mengenai aktivitas antimikroba ekstrak bunga tembelekan terfraksinasi menggunakan pelarut yang berbeda-beda berdasarkan tingkat kepolarannya. Penggunaan variasi kepolaran pelarut diharapkan 
menghasilkan ekstrak dengan aktivitas antibakteri tertinggi. Jenis pelarut yang biasa digunakan dalam proses ekstraksi sampel yaitu etanol, etil asetat dan $n$ heksan. Variasi pelarut perlu dilakukan karena senyawa senyawa aktif yang berpotensi sebagai antimikroba dalam daun tembelekan belum diketahui sifat kepolarannya.

\section{METODE PENELITIAN}

\section{Bahan dan Peralatan}

Bahan yang digunakan dalam penelitian ini mencakup bunga tembelekan (bunga warnah kuning). Bahan lainnya berupa bakteri patogen Streptococcus mutans, Vibrio chorela, Nutrien Agar (NA), aquades, $n$-heksan, etil asetat, etanol, kloramfenikol, dan asam asetat anhidrat.

Peralatan yang digunakan pada penelitian ini yakni aluminium foil, blender, ayakan 60 mesh, oven, autoclaf, inkubator, laminar, jangka sorong, botol semprot, spatula, bunsen, jarum ose, neraca dan alat-alat gelas yang umum digunakan dalam Laboratorium Kimia.

\section{Prosedur Penelitian}

\section{Ekstraksi Bunga Tembelekan}

Ekstraksi dilakukan menggunakan metode maserasi menggunakan tiga jenis pelarut. Ekstraksi pertama diguna kan pelarut non polar yakni $n$-heksan dengan cara menimbang tepung bunga tembelekan sebanyak 50 gram, kemudian dimasukkan ke dalam erlenmeyer $1000 \mathrm{ml}$ lalu ditambahkan $500 \mathrm{ml}$ n-heksan (perbandingan pelarut dan sampel $1: 10$ ). Campuran disimpan selama $2 \times 24$ jam sambil sesekali dikocok, kemudian disaring dengan penyaringan vakum. Filtrat yang diperoleh dipisahkan pelarutnya dengan rotary vakum evaporator sehingga didapatkan ekstrak kental bunga tembelekan. Sedangkan residu yang diperoleh dikering - anginkan selanjutnya dimasukkan ke dalam erlenmeyer untuk diekstrak kembali dengan pelarut etil asetat, kemudian dilanjutkan menggunakan pelarut etanol, dengan perlakuan yang sama pada ekstrak menggunakan $n$-heksan.

\section{Persiapan Bahan Uji Antibakteri}

Sebanyak 28 g nutrient agar (NA) dilarutkan dalam $1000 \mathrm{ml}$ aquades, kemudian di sterilkan kedalam autoclave pada suhu $121^{\circ} \mathrm{C}$ dengan tekanan $1 \mathrm{~atm}$ selama 15 menit.

\section{Pembuatan Suspensi Bakteri Uji}

Satu mata ose bakteri diambil dari biakan agar miring baru dan diinokulasikan ke dalam media cair steril Nutrient Broth, kemudian diinkubasi selama 24 jam pada suhu $37^{\circ} \mathrm{C}$. Kultur bakteri siap digunakan untuk pengujian aktivitas antibakteri.

\section{Pengujian Aktivitas Antibakteri}

Pada pengujian zona hambat bakteri digunakan metode sumur difusi. Media Nutrien Agar (NA) sebanyak $25 \mathrm{ml}$ dicampur dengan $25 \mu \mathrm{L}$ suspensi bakteri uji (Streptococcus mutans dan Vibrio chorela), dihomogenkan lalu dituang 
dalam cawan petri steril dan dibiarkan sampai memadat. Setelah itu dibuat sumur yang berdiameter $\pm 6 \mathrm{~mm}$ dengan menggunakan Cork Borer. Setiap cawan berisi 5 lubang atau sumur (lubang pertama untuk control negative berupa pelarut $n$-hekasan, etil asetat, dan etanol. Lubang kedua untuk kontrol positif berupa kloramfenikol dan 3 lubang untuk 3 jenis ekstrak), setiap sumur diisi ekstrak dengan control sebanyak $30 \mu \mathrm{L}$, kemudian diinkubasi selama 24 jam pada suhu $37^{\circ} \mathrm{C}$, selanjutnya diamati dan diukur diameter zona hambat dengan jangka sorong.

\section{HASIL DAN PEMBAHASAN}

\section{Metabolit Sekunder dalam Ekstrak Bunga Tembelekan}

Pada Tabel 1 terlihat bahwa ekstrak $n$-heksan terdeteksi adanya steroid tetapi tidak terdeteksi adanya alkaloid, flavonoid, alkaloid, saponin, dan tanin. Hal tersebut menunjukan bahwa dalam bunga tembelekan terdapat senyawa steroid yang bersifat nonpolar. Ini sesuai dengan pendapat Lestiani dan lanny (2008), tingkat kepolaran pelarut menentukan jenis dan jumlah senyawa yang dapat diekstrak dari bahan. Ekstrak etil asetat terdeteksi adanya alkaloid dan tanin. Alkaloid dan tanin yang ada dalam fraksi etil asetat pada bunga tembelekan terdiri atas alkaloid dan tanin semi-polar serta alkaloid dan tanin polar. Fakta-fakta ini sesuai dengan apa yang dilaporkan oleh Dewi (2013) dalam Simaremare (2014) menyatakan bahwa senyawa golongan alkaloid memilik atom nitrogen dalam sistem sikliknya dan tersubtitusi beberapa gugus, seperti amida, amina, metoksi, dan fenol sehingga alkaloid cenderung bersifat semipolar.

Tabel 1 Hasil analisis golongan senyawa ekstrak bunga tembelekan dari ketiga jenis pelarut.

\begin{tabular}{cccc}
\hline \multirow{2}{*}{$\begin{array}{c}\text { Golongan } \\
\text { senyawa }\end{array}$} & \multicolumn{3}{c}{ jenis ekstrak dengan pelarut } \\
\cline { 2 - 4 } & $\begin{array}{c}n- \\
\text { heksan }\end{array}$ & $\begin{array}{c}\text { Etil } \\
\text { asetat }\end{array}$ & Etanol \\
\hline Flavonoid & - & - & ++ \\
Alkaloid & - & ++ & + \\
Steroid & + & - & - \\
Saponin & - & - & ++ \\
Tanin & - & ++ & +++ \\
\hline
\end{tabular}

Keterangan :

$(+)$ : Terdeteksi adanya senyawa

$(-)$ : Tidak terdeteksi adanya senyawa

Pada Tabel 1 juga terlihat bahwa senyawa flavonoid dan saponin terdeteksi dalam ekstrak etanol, tetapi tidak terdeteksi dalam ekstrak etil asetat maupun ekstrak n-heksan, yang menunjukan flavonoid dan saponin yang ada dalam bunga tembelekan adalah flavonoid dan saponin yang bersifat polar. Senyawa golongan flavonoid memiliki ikatan dengan gugus gula menyebabkan flovonoid bersifat polar (Shimaremare 2014). Saponin termasuk senyawa glikosida triterpen yang memiliki ikatan glikosida sehingga cenderung bersifat polar (Sangi et al., 2013), sedangkan senyawa tanin merupakan senyawa fenolik yang memiliki kelarutan cukup tinggi dalam pelarut polar, seprti air (Harborne 1996). 


\section{Uji Aktivitas Antibakteri dan Daya Hambat Ekstrak Bunga Tembelekan.}

Berdasarkan hasil penelitian dari 2 bakteri masing-masing 3 kali pengulangan diperoleh perbedaan zona hambat dari masing-masing ekstrak $n$-heksan, etil asetat dan etanol. Uji aktivitas ekstrak bunga tembelekan terhadap pertumbuhan bakteri gram positif (Streptococcus mutans) dan gram negatif (Vibrio cholera) dengan menggunakan metode sumur difusi, yang di tandai dengan terbentuknya zona bening di sekitar sumuran. Antibiotik Chloramphenicol sebagai kontrol positif dan kontrol negatif berupa 3 pelarut yaitu $n$-heksan, etil asetat dan etanol. Pengamatan terhadap diameter zona hambat dari masing-masing ekstrak dengan pengukuran menggunakan jangka sorong otomatis. disajikan dalam Gambar 2, sedangkan pengukuran diameter zona hambat disajikan pada tabel lampiran.

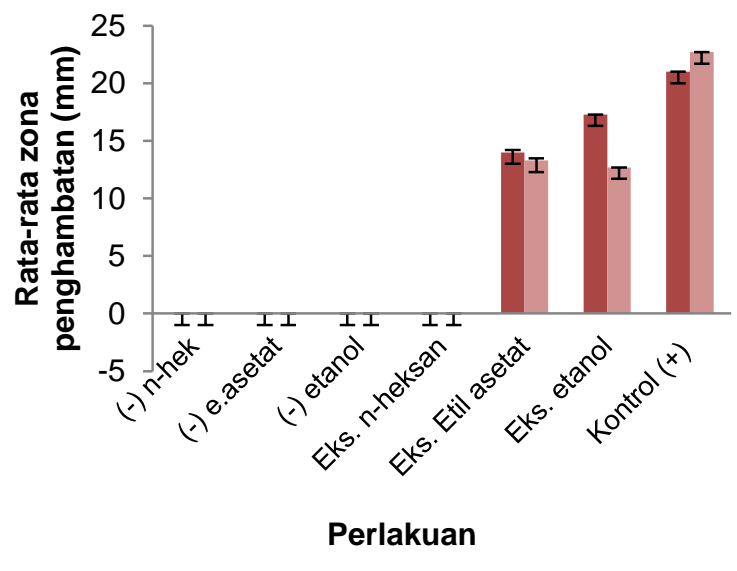

- Vibrio cholera - Streptococcus mutans

Gambar 2 Diameter rata-rata Zona Hambat Ekstrak Bunga Tembelekan Terhadap Pertumbuhan Bakteri Sterptococcus mutans dan Vibrio cholerae
Gambar 2 memperlihatkan bahwa pada kontrol negatif ( $n$-heksan, etil asetat dan etanol) tidak menunjukan adanya daya hambat karena dalam kontrol negatif tidak mengandung senyawa yang berperan sebagai antibakteri. Pada ekstrak etanol dan ekstrak etil asetat mengandung senyawa yang berperan pada antibakteri, dapat dilihat dari zona hambat yang dihasilkan. Sedangkan pada ekstrak $n$-heksan tidak mempunyai daya hambat, karena pada ekstrak $n$-heksan tidak mampu menarik senyawa antibakteri yang ada pada bunga tembelekan, sehingga tidak mampu menghambat pertumbuhan bakteri patogen Vibrio cholera maupun Streptococcus mutans.

Tabel 2 Hasil zona hambat bakteri gram negatif Vibrio cholera dan bakteri gram positif Streptococcus mutans.

\begin{tabular}{ccc}
\hline \multirow{2}{*}{$\begin{array}{c}\text { Jenis ekstrak } \\
\text { dan kontrol }\end{array}$} & \multicolumn{2}{c}{$\begin{array}{c}\text { Diameter Rata-rata Zona } \\
\text { Hambat (mm) }\end{array}$} \\
\cline { 2 - 3 } & $\begin{array}{c}\text { Vibrio } \\
\text { cholerae }\end{array}$ & $\begin{array}{c}\text { Streptococcus } \\
\text { mutans }\end{array}$ \\
\hline $\begin{array}{c}\text { Ekstrak } n \text { - } \\
\text { heksan }\end{array}$ & 0 & 0 \\
$\begin{array}{c}\text { Ekstrak Etil } \\
\text { asetat }\end{array}$ & 17,3 & 12,7 \\
$\begin{array}{c}\text { Ekstrak Etanol } \\
\text { Kontrol positif }\end{array}$ & 14 & 13,3 \\
Chloramphenicol & 21 & 22,7 \\
\multicolumn{2}{c}{$\begin{array}{c}\text { Etanol } \\
\text { Kontrol negatif }\end{array}$} \\
$\begin{array}{c}\text { Etil asetat } \\
n \text {-Heksan }\end{array}$ & 0 & 0 \\
\hline
\end{tabular}

Tabel 2 menunjukan ekstak $n$ heksan tidak memperlihatkan daya hambat terhadap bakteri uji berupa (Vibrio cholerae dan Streptococcus mutans). Dengan demikian steroid non polar pada bunga tembelekan tidak bersifat antibakteri. Abhishek et al.., (2013) dan 
Ekwenchi et al.., (2014) melaporkan bahwa $n$-Heksan sebagai kontrol negatif tidak memiliki aktivitas antibakteri terhadap bakteri gram positif dan gram negatif. Selain itu Parekh et al.., (2005) juga menemukan bahwa, aktivitas antibakteri dipengaruhi oleh polaritas senyawa yang diekstraksi oleh masingmasing pelarut dengan kemampuan zat tersebut untuk menyebar pada media yang digunakan dalam pengujian aktivitas antibakteri. Tetapi ekstrak $n$-heksan pada bakteri Streptococus pyogenes, shigela dysenteriae dan Micrococus luetus memberikan daya hambat.

Ekstrak etil asetat yang mengandung alkaloid semi polar dan tanin semi polar memberikan zona hambat terhadap semua bakteri uji, meskipun diameter zona hambatnya berbeda. Diameter zona hambat tertinggi $(17,3 \mathrm{~mm})$ ditemukan pada Vibrio cholerae dan zona hambat terendah $(12,7 \mathrm{~mm})$ terdapat pada bakteri uji Streptococus mutans. Mekanisme kerja senyawa alkaloid sebagai antibakteri adalah dengan cara menganggu kompenen penyusun peptidoglikan pada sel bakteri, sehingga menyebabkan kematian sel bakteri. Kelompok senyawa apa dalam ekstrak etil asetat yang berperan sebagai antibakteri belum dapat ditemukan, perlu pengujian lanjut sebab dalam ekstrak etil asetat terdapat 2 kelompok senyawa. Jika diasumsikan hanya satu jenis senyawa yang berperan sebagai antibakteri, maka senyawa semipolar dalam bunga tembelekan memiliki spektrum penghambatan yang luas terhadap bakteri dibanding dengan Chloramphenicol.

Ekstrak etanol mengandung senyawa-senyawa polar (flavonoid, saponin, steroid dan tanin) juga memberikan zona hambat terhadap kedua bakteri uji. Zona hambat lebih tinggi (14 $\mathrm{mm}$ ) ditemukan pada Vibrio cholera daripada zona hambat pada Streptococcus mutans (13,3 mm). Kandungan flavonoid pada ekstrak etanol berperan dalam menggangu proses metabolisme pada bakteri dengan cara pembentukan ikatan antara protein dari bakteri dengan senya fenol dari flavonoid (Ganiswara, 1995). Gugus fungsi yang berperan sebagai antibakteri adalah gugus hidroksil $(\mathrm{OH})$ dimana prinsip kerjanya dengan menghambat sintesis asam nukleat dan metabolisme energi dari bakteri. Sabir (2005) menjelaskan bahwa gugus $-\mathrm{OH}$ pada flavonoid berperan sebagai toksik terhadap bakteri, sedangkan senyawa saponin dapat menyebabkan hemolisis pada sel darah merah. Hal ini disebabkan karena saponin berikatan dengan kolestrol dari membran sel sehingga dapat merusak membran (Faradisa, 2008).

Sementara untuk ekstrak tanin memiliki campuran senyawa polifenol kompleks yang umumnya berikatan dengan karbohidrat sederhana, seperti glukosa (Linggawati et al., 2002). Tanin berperan sebagai antibakteri dengan cara mengganggu sintesis senyawa 
peptidoglikan pada bakteri sehingga pembentukan dinding sel bakteri menjadi terhambat atau kurang sempurna. Pada control negatif semua pelarut tidak menunjukkan aktivitas antibakteri. Etanol absolut memiliki efek bakterisidal yang lebih lemah dibandingkan campuran antara alkohol dan air. Meskipun demikian, etanol pada konsentrasi 60-99\% masih dapat menghambat pertumbuhan gram negatif (Ali et al.., 2001).

Menurut Schlegel (1993), bahwa senyawa/ pelarut dapat memberikan efek yang berbeda dalam menghambat pertumbuhan bakteri. Metabolit sekunder dalam ekstrak tembelekan memiliki efek antibakteri yang berbeda-beda tergantung pada sifat dan morfologi bakteri. Faktor lain yang menyebabkan perbedaan diameter zona hambat dari ekstrak adalah perbedaan senyawa aktif yang terdapat pada ekstak. Prescott (2005) menjelaskan bahwa uji aktivitas antibakteri mengunakan metode sumur difusi dipengaruhi oleh beberapa faktor, seperti tingkat sensitifitas dari organisme uji, kecepatan difusi dan konsentrasi senyawa antibakteri.

Menurut Davis dan Stout (1971) dalam Kumesan et al. (2013), kekuatan sifat antibakteri berdasarkan zona bening yang terbentuk, maka dikelompokkan menjadi 4 bagian,yaitu sangat kuat bila zona hambat $>20 \mathrm{~mm}$, kuat $10-20 \mathrm{~mm}$, sedang 5-10 mm, dan lemah $<5 \mathrm{~mm}$. Berdasarkan pernyataan Davis dan Stout (1971) Senyawa antibakteri dalam ekstrak etanol bunga tembelekan termasuk antibakteri zona hambat kuat terhadap Vibrio cholera dan daya hambat kuat terhadap Streptococcus mutans. Untuk senyawa antibakteri dalam ekstrak etil asetat juga termasuk anti bakteri daya hambat kuat terhadap bakteri Vibrio cholera dan daya hambat kuat terhadap Streptococcus mutans.

\section{KESIMPULAN}

Ekstrak bunga tembelekan mengandung senyawa antibakteri yang bersifat non polar, yaitu steroid, senyawa semi polar yaitu alkaloid dan tanin serta senyawa polar yaitu flavonoid, alkaloid, saponin dan tannin. Zona hambat tertinggi ekstrak bunga tembelekan terhadap bakteri gram positif diperoleh dari ekstrak etanol 13,3 $\mathrm{mm}$ pada bakteri Streptococcus mutans. Sedangkan pada bakteri gram negatif diperoleh dari ekstrak etil asetat $17,3 \mathrm{~mm}$ pada bakteri Vibrio cholera.

\section{DAFTAR PUSTAKA}

Abhishek, S., Ujwala, P., Shivani, K., dan meeta, B. 2013. Antibacterial activity of Tecomella undulata leaves crude extrack. International Journal of Biological Sciences 2(6):60-62.

Ali, Y., Dolan, M. J., dan Larson, E. L. 2001. Alcohol. Dalam Block, S. S. (ed). 2001. Disinfections, Sterilization, and Preservation. Edisi ke- 5. Philadelphia: Lippincott Williams and Wilkins, Halaman 231 dan 234. 
Asma, St. N., Dini, I., Danial, M. 2015. Isolasi dan Identifikasi Senyawa Metabolit Sekunder Ekstrak Kloroform Daun Tembelekan (Lantana camara linn.) Dan Uji Potensi Sebagai Senyawa Antibakteri Alami. Chemica: Jurnal IImiah Kimia Dan Pendidikan Kimia, 16(2): 92-102.

Copriady. Jimmi, Elva Yasmi, dan Handayani. 2005. Isolasi dan karakterisasi senyawa kumarin dari kulit buah jeruk purut (Citrus hystrix DC). Jurnal Biogenesis, 2(1):13-15.

Davis, W.W. dan T.R. Stout.1971. disc Plate Methods of Microbiological Antibiotic Assay. Microbiology, 2(4): 659-665.

Ekwenchi, M.M., Oluigbo, J., dan Akpuaka, A. 2014. Antibacterial activity of $n$-hexane extract of Ocimum gtratissimum leaves. IOSR Journal of Applied Chemistry 7(5): 610.

Fajrullah, A. 2014. Ekstraksi Senyawa Metabolit Sekunder Lamun Thalassodendron ciliatum Pada Pelarut Berbeda. Skripsi. Tanjung Pinang: Universitas Maritim.

Faradisa, M. 2008. Uji Efektifitas Antimikroba Senyawa Saponin dari Batang Tanaman Belimbing Wuluh (Averrhoa bilimbi Linn). Skripsi. Malang: Fakultas Sains dan Teknologi. UIN Malang.

Ganiswara, S.G., 1995, Farmakologi dan Terapi, Edisi 4, Jakarta: Bagian Farmakologi FKUI.

Harborne, J.B. 1996. Methode Fitokimia Penuntun cara Modern Menganalisis Tumbuhan. Bandung : Penerbit ITB. p.76-153.
Iwan, D., Muharram., Sitti F. 2011. Potensi ekstrak Tumbuhan Tembelekan (Lantana camara Linn) dalam Menghambat Pertumbuhan Bakteri Staphylococcus aureus dan Escheria coli). Bionature, 12(1): 21 25.

Kumesan, Y A N., Yamlean, V Y., Supriati, H S. 2013. Formulasi dan Uji Aktivitas Gel Antijerawat Ekstrak Umbi Bakung (Crinum asiaticum L.) Terhadap Bakteri Staphylococcus aureus secara in Vitro. Pharmacon: Jurnal IImia Farmasi, 2(2): 18-26.

Lestiani dan lanny. 2008. Vitamin Larut Air. Jakarta: Universitas Indonesia.

Linggawati A. 2002. Pemanfaatan Tannin Limbah Kayu Industri Kayu Lapis Untuk Modifikasi Resin Fenol Formaldehid. Jurnal Natur Indonesia 5(1):84-94.

Parekh, J,. Jadeja, D., Chandra, S. 2005. Efficaccy of Aqueous and Mathanol Extracts of Some Medicinal Plants for Potential Antibacterial Activity. Turk $J$ Biol. 29: 203-210.

Prescott, LM. 2005. Microbiology. New York: Mc.Grow-Hill.

Rijay. 2014. Mikrobiologi dan Parasitologi. Bandung: PT Citra Aditya Bakti.

Sabir, A. 2005. Aktivitas antibakteri flavonoid propolis Trigona $\mathrm{sp}$ terhadap bakteri Streptococcus mutans (in vitro). Maj. Ked. Gigi. (Dent. J.), 38: 135-41.

Sangi, m., Runtuwene, M.R.J., Simbala, H.E.I., dan Makang, V.M.A. 2008. Analisis Fitokimia Tumbuhan Obat di Kabupaten Minahas Utara, Chemistry Progress, 1(1): 47-53. 
Schlegel, G. Hans. 1993. General Microbiologi. Seventh Edition. England: Cambridge University Press.

Simaremare, E. S. 2014. Skrining fitokimia Ekstrak Etanol Daun Gatal (Laporteae decumana (Roxb) Wedd). Pharmacy, 11(1):98-107.

Tjay Tan Hoan dan Kirana Rahardja. 2002. Obat-Obat Penting Ed. 7. Jakarta: PT Medi Box Kompusindo. 